
\title{
25 Research Square \\ Effects of Potassium Management on Physiological Traiats, Enzyme Activity and Cotton Fiber Cellulose Content
}

Fábio Echer ( $\nabla$ fabioecher@unoeste.br)

Universidade do Oeste Paulista https://orcid.org/0000-0003-0140-7999

Vinicius José Souza Perez

Universidade do Oeste Paulista

Giuliano Oliveira Carnevalli Baltazar

Universidade do Oeste Paulista

Gustavo Ricardo Aguiar Silva

Universidade do Oeste Paulista

Adriana Lima Moro

Universidade do Oeste Paulista

Pedro Henrique Gorni

Universidade do Oeste Paulista

Ciro Antonio Rosolem

São Paulo State University

\section{Research Article}

Keywords: Gossypium hirsutum L., enzyme regulations, leaf area index, stomata conductance

Posted Date: August 30th, 2021

DOl: https://doi.org/10.21203/rs.3.rs-831885/v1

License: (c) (i) This work is licensed under a Creative Commons Attribution 4.0 International License.

Read Full License 


\section{Abstract}

Aims

Potassium (K) is prone to be washed out of plant tissues independent of mineralization since it is not strongly bound to organic structures in the plant. Therefore, cover crops can enhance K cycling in cropping systems increasing the nutrient use efficiency by taking it up deep in the soil profile and releasing it on the soil surface. However, it is not clear if this cycling would have an effect on cotton morphophysiology, enzyme activity, and eventually on fiber quality.

Methods

Potassium was applied to two cotton cultivars, either to the cover crop ruzigrass (Urochloa ruzisiensis), or to cotton grown after the grass or not, and split between the cover crop and cotton.

Results

Cotton leaf area index was increased late in the season by $\mathrm{K}$, with small differences between fertilized treatments, but was highest at full bloom when at least part of the K was applied to cotton. Stomatal conductance was improved, mainly late in the season and when cotton was grown after ruzigrass. Consequently, the enzymatic activity and accumulation of cellulose in the cotton fiber were also increased.

Conclusion

Potassium fertilization improves cotton physiological parameters such as leaf area index and stomatal conductance, but the effect on enzyme activity depends on the enzyme and on the cotton cultivar. Early cellulose accumulation in the fiber is favored by potassium fertilization and cotton rotation with ruzigrass.

\section{Highlights}

- Cotton leaf area index was increased late in the season by $\mathrm{K}$.

- Stomatal conductance was improved late in the season when cotton was grown after ruzigrass.

- Enzymatic activity (SuSy, SPS and SI) and accumulation of cellulose in the cotton fiber were increased by $\mathrm{K}$ fertilization.

- Early cellulose accumulation in the fiber is favored by potassium fertilization and cotton rotation with ruzigrass.

- Fiber maturity was higher when $\mathrm{K}$ was applied to the grass or split in the grass and sidedressed in cotton. 


\section{Introduction}

Depending on crop yield, cotton K uptake ranges from 190 to $415 \mathrm{~kg} \mathrm{ha}^{-1}$ (Vieira et al. 2018; Rosolem et al. 2012; Rochester et al. 2007). The maximum uptake rate of $3.2 \mathrm{~kg} \mathrm{ha}^{-1} \mathrm{day}^{-1}$ was observed during boll filing stage ( $115 \mathrm{DAE})$, but around $61 \%$ of the $\mathrm{K}$ was taken up during flowering in a high yielding field in Australia (Rochester et al. 2012). Potassium exports in fibers and seeds ranges from $15 \%$ to $21 \%$ of the total taken up, considering lint yields from 1,000 to $2,400 \mathrm{~kg} \mathrm{ha}^{-1}$ (Rochester et al. 2007). During fruit development $\mathrm{K}$ translocation to fruits is intense (Ali et al. 2018), resulting in high $\mathrm{K}$ concentration in the fruit capsules. The fruit, including its peel, is the dominant $\mathrm{K}$ drain in the plant (Rosolem and Mikkelsen 1991).

Potassium plays an important role in plant metabolism, growth, development and yield. It is essential for the optimal functioning of the plant's photosynthetic apparatus due to its role in stomata regulation and enzyme activation, in rubisco activity and chlorophyl concentration (Dana et al. 2016; Wang et al. 2017; Shabala 2017; Parveen et al. 2020). Potassium also activates enzymes related to sucrose and starch transformation, which is mainly responsible for carbon metabolism (Kahrizi et al. 2010; Ali et al. 2018; Parveen et al. 2020). The deficiency of $\mathrm{K}$ impairs leaf area expansion and $\mathrm{CO}_{2}$ assimilation capacity (Gerardeaux et al. 2010), as well as numerous physiological functions, including water relations, enzymatic activation, charge balance, stress resistance an eventually cotton growth and yield (Oosterhuis et al. 2013). Fiber quality is paramount for cotton comercialization, and $\mathrm{K}$ deficiency can result in less cellulose deposition on the secondary fiber wall, harming fiber maturity, micronaire, length, and uniformity (Hu et al. 2018). The lack of $\mathrm{K}$ results in an early maturing plant, with shorter cycle (Silva et al. 1995), decreased seed and boll weights and fiber yield (Pettigrew et al. 1996; Yang et al. 2012). Fiber strength can be decreased by $\mathrm{K}$ deficiency due to the nutrient role in building "bridges" between cellulose chains in the cotton fiber (Lima and Bélot 2019). A decrease in activity of key enzymes such as sucrose synthase (SuSy), can affect cellulose deposition in the fiber, and consequently, fiber strength, short fiber index and maturity (Raphael et al. 2019). Sucrose synthase (SuSy) plays two fundamental roles: sucrose synthesis and decomposition (Tung et al. 2018). Acid invertase acts on the hydrolysis of sucrose to glucose and fructose (Hu et al. 2015) and sucrose phosphate synthase (SPS) is linked to the regulation of the carbon partition between sucrose and starch in the leaves (Huber and Huber 1996). The activity of these enzymes is dependent on $\mathrm{K}$ nutrition (Hafeez et al. 2019; Hu et al. 2015). Therefore, $\mathrm{K}$ regulates photoassimilation and translocation simultaneously with the enzyme activities (Zahoor et al. 2017). When $\mathrm{K}$ deficiency occurs during fiber elongation, the decrease in turgor pressure results in shorter fibers (Rosolem and Bogiani 2014). As this nutrient is associated with sugar transport in the plant, it is likely that $\mathrm{K}$ deficiency may affect the deposition of cellulose microfibrils on the secondary wall in cotton fibers, thus decreasing fiber resistance and micronaire.

Sandy soils show low natural fertility, water retention, and cation exchange capacity due to the low levels of organic matter and clay, and are prone to $\mathrm{K}$ leaching. Potassium chloride, the main source of $\mathrm{K}$ for agriculture, was shown to have high mobility in the soil profile, mainly in sandy soils with low CEC (Werle et al. 2008) because K adsorption to soil colloids is low (Duiker and Bleeg 2006). Since drainage is fast in 
sandy soils, $\mathrm{K}$ percolation in the soil profile below the rooting zone can impair fertilizer use efficiency during the rainy season (Rosolem et al. 2006). To avoid $\mathrm{K}$ loss, it has been traditionally recommended to split rates above $50 \mathrm{~kg} \mathrm{ha}^{-1}$ of $\mathrm{K}_{2} \mathrm{O}$ (Foloni and Rosolem 2008; Bernardi et al. 2009). Antoher strategy suggested to improve fertilizer use efficiency in sandy soils is applying fertilizer to cover crops such as grasses of the genera Urochloa grown before cotton, because the $\mathrm{K}$ taken up returns to the soil mimicking a slow-release fertilizer (Echer et al. 2020). Therefore, we hypothesized that $\mathrm{K}$ application to the cover crop grown before cotton can avoid the effects of $\mathrm{K}$ defficiency in cotton physiological performance and result in better fiber quality by improving the fertilizer use efficiency.

The aim of this work was to assess leaf area index, stomatal conductance, enzymatic activities of sucrose transport and cellulose contents of two cotton cultivars as affected by $\mathrm{K}$ fertilizer management and the use of ruzigrass as a cover crop.

\section{Materials And Methods}

Field experiments were conducted in the 2016/17 and 2017/18 cropping seasons in Presidente Bernardes, São Paulo, Brazil, 22 ${ }^{\circ} 07^{\prime} 32^{\prime \prime} \mathrm{S}$ and $51^{\circ} 23^{\prime} 20^{\prime \prime} \mathrm{W}, 475 \mathrm{~m}$ asl. The soil is a typic Rhodustult, sandy loam (USDA 2010). The climate is tropical with dry winters and wet, hot summers. Soil samples were taken at the depths of 0 to $20 \mathrm{~cm}$ and 20 to $40 \mathrm{~cm}$ on May 05,2016 , for chemical analysis as in Raij et al. (2001). Selected chemical and particle size distribution of the soil are in Table 1. Lime (45\% of CaO and $4.9 \%$ of $\mathrm{MgO}$ ) was broadcast on the soil surface at 1,400 kg ha-1 in September 2016 and 2,000 kg ha1 in October 2017. Rainfall, maximum and minimum temperatures, and vapor pressure deficit during the experiment are shown in Figure 1.

The treatments were an early (FM 913GLT) and a late (FM 983GLT) cotton cultivar and six K fertilization schemes (Table 2). Treatments were repeated in the same plots in both seasons. The experimental design was a $2 \times 6$ factorial in complete randomized blocks with five replicates. Each plot had four 7.0-m cotton rows spaced $0.8 \mathrm{~m}$ from each other. The two outer rows and 1.0 at the end of each row were considered borders and not included in evaluations.

Ruzigrass was sown on May 05, 2016, and June 06, 2017 using $14 \mathrm{~kg} \mathrm{ha}^{-1}$ pure viable seeds. Potassium fertilizer was applied to the grass in the corresponding treatments early September each year, using potassium chloride. Ruzigrass was desiccated on November 1, 2016 and November 6, 2017, using glyphosate (1.92 $\mathrm{g} \mathrm{ha}^{-1}$ a.i.), and cotton was sown on December 9, 2016, and November 23, 2017. Phosphorus was applied at $56 \mathrm{~kg} \mathrm{ha}^{-1}$ and $\mathrm{N}$ at $30 \mathrm{~kg} \mathrm{ha}^{-1}$ as mono ammonium phosphate at cotton planting. The rate of $140 \mathrm{~kg} \mathrm{ha}^{-1}$ of $\mathrm{N}$ was side dressed and equally split 35 and 45 days after plant emergence (DAE), using ammonium sulphate and urea, respectively. Boric acid was sprayed at $2.0 \mathrm{~kg} \mathrm{ha}^{-1}$ split into 4 weekly applications from the first flower. Weed, pests, and diseases were controlled according to standard farm practices in São Paulo State. Seven days before harvest plants were defoliated with 
Tidiazurom (60 $\mathrm{g} \mathrm{ha}^{-1} \mathrm{a}$ a.i.) + Diuron (30 $\left.\mathrm{g} \mathrm{ha}^{-1} \mathrm{a} . \mathrm{i}\right)$. Cotton was handpicked 141 and 132 DAE in 2016/17 and $2017 / 18$, respectively.

Leaf area index and stomatal conductance $-1^{\text {st }}$ and $2^{\text {nd }}$ season

Leaf area index was measured at 30,60, 90, and 120 days after emergence using a ceptometer (Accupar LP-80 - Decagon Devices) in three sub-samples per plot in both seasons. Stomatal conductance was evaluated at early flowering, full flowering and early boll-opening stage (F1, F7 and C2, respectively, according to Marur and Ruano, 2001) using a porometer (SC1-Decagon Devices) from 10 AM to 2 PM in two sub-samples per plot.

Enzyme assay $-2^{\text {nd }}$ season

At mid flowering (F6/F7 stage - Marur and Ruano 2001), twelve plants per plot had their first position flowers tagged, and 24 days later (24 DAA) four bolls and their leaves were collected. At 48 DAA only bolls were collected since leaves were absent. This material was ground to a fine powder in liquid nitrogen. Tissue was extracted in a ratio of $500 \mathrm{mg}$ of tissue to $3.5 \mathrm{~mL}$ of extraction buffer. The extraction buffer contained $50 \mathrm{mM}$ Hepes ( $\mathrm{pH}$ 7.5), $10 \mathrm{mM} \mathrm{MgCl}, 1 \mathrm{mM}$ EDTA (Grof et al. 2007). Extracts were centrifuged at $14,000 \mathrm{rpm}$ at $4{ }^{\circ} \mathrm{C}$ for 20 minutes to remove coarse material. Extracts were then desalted using Dowex $1 \times 4$ for 10 minutes and centrifuged at $10,000 \mathrm{rpm}$ at $4{ }^{\circ} \mathrm{C}$ for 10 minutes, the supernatant was collected and the Sucrose Phosphate Synthase (SPS), Sucrose Synthase (SuSy) and Soluble Acid Invertase (SAI) were analyzed. All procedures were done at $4{ }^{\circ} \mathrm{C}$. Enzymes were assayed immediately in duplicate. Protein measurement was performed as in Bradford (1976), using bovine serum albumin as standard.

SPS - Sucrose Phosphate Synthase (EC 2.4.1.14)

Total SPS activities were assayed by measuring the synthesis of SUC-6-P (Sucrose) (and SUC) from UDPGlc (glucose) and Fru-6-P (fructose) (Huber and Huber 1991). Each reaction contained $20 \mathrm{mM}$ UDP-Glc, 5 $\mathrm{mM}$ Fru-6-P, $17.5 \mathrm{mM}$ Glc-6-P, and $50 \mu \mathrm{L}$ of extract in a total volume of $100 \mu \mathrm{L}$. The reaction was started by the addition of extract and incubated at $25^{\circ} \mathrm{C}$ for $10 \mathrm{~min}$. After stopping the reaction with $100 \mu \mathrm{L}$ of 5 $\mathrm{M} \mathrm{KOH}$ and $10 \mathrm{~min}$ of heating at $100^{\circ} \mathrm{C}$ to destroy unreacted hexoses and hexose phosphates, $1 \mathrm{~mL}$ of $0.14 \%(\mathrm{w} / \mathrm{v})$ anthrone in $80 \%(\mathrm{v} / \mathrm{v}) \mathrm{H}_{2} \mathrm{SO}_{4}$, was added before $40 \mathrm{~min}$ of incubation at $40{ }^{\circ} \mathrm{C}$. SUC-6-P (and SUC) content was determined by comparing the $A_{628}$ to that of a standard curve ( $0-200 \mathrm{nmol}$ of SUC). The recovery of Suc was estimated by incubating $50 \mu \mathrm{L}$ of extract with $100 \mathrm{nmol}$ of Suc under the above assay conditions.

SuSy - Sucrose Synthase (EC 2.4.1.13)

UDP-dependent cleavage of Suc into UDP-Glc and Fru was assayed (Copeland 1990). Each reaction contained $20 \mathrm{mM}$ Hepes-KOH, pH 6.5, $100 \mathrm{mM}$ Suc, $2 \mathrm{mM}$ UDP, and $20 \mu \mathrm{L}$ of extract in a total volume of $250 \mu \mathrm{L}$. Control reactions lacked UDP. Reactions were started by the addition of extract and incubated at 
$25^{\circ} \mathrm{C}$ for $30 \mathrm{~min}$. The reactions were stopped with $250 \mathrm{pL}$ of $0.5 \mathrm{M}$ Tricine- $\mathrm{KOH}, \mathrm{pH} 8.3$, and boiling for 10 min. Suc was measured spectrophotometrically, as described above.

SAl - Soluble Acid Invertase (EC 3.2.7.26)

SAl was measured by incubation of $20 \mu \mathrm{L}$ of extract with $100 \mathrm{mM}$ Suc in $100 \mathrm{mM}$ acetic acid-NaOH, pH 5.0 , in a total volume of $250 \mu \mathrm{L}$. Reactions were started by the addition of extract and incubated at $25^{\circ} \mathrm{C}$ for $30 \mathrm{~min}$. The reactions were stopped with $250 \mu \mathrm{L}$ of $0.5 \mathrm{M}$ Tricine- $\mathrm{KOH}, \mathrm{pH} 8.3$, and boiling for $10 \mathrm{~min}$. Control reactions contained boiled extract, and Glc was measured spectrophotometrically, as described above (King et al. 1997).

Determination of cellulose in cotton fiber $-2^{\text {nd }}$ season

Fruit samples were taken from the first position (P1) of the $10^{\text {th }}$ sympodial branch 24 and 48 days after anthesis and dried in a forced-air oven at $65{ }^{\circ} \mathrm{C}$ for 96 hours. Determinations were conducted in three replications, according to Van Soest et al. (1991). The acid-detergent fiber (ADF) content was determined using an acid detergent (trimethylammonium bromide, standardized sulfuric acid. After examining the ADF content, the cellulose content was assayed in cotton samples using a standardized solution of sulfuric acid.

\section{Statistical analysis}

After testing for homogeneity and normality, data were submitted to ANOVA. The experiment was arranged in a complete randomized block design in a $2 \times 6$ factorial scheme (cultivars $\times \mathrm{K}$ management) and five replicates. The data were analyzed with three-way (cultivar, $\mathrm{K}$ management and year) analysis of variance and Tukey test $(P<0.05)$ was used to compare treatment means. When the differences between cultivars were not significant, their averages were presented and discussed.

Multivariate analysis was performed via principal component analysis (PCA) to verify the grouping of the different responses to $K$ fertilizer management and the use of ruzigrass in the second year (2017/2018). Considering that the measurement units differed between variables, the data were log-transformed to reduce the effect of the numeric scale (McGarigal et al. 2000). The ordination graphic (with two major components) was demarcated by two axes designated as the first (PC1) and second (PC2) principal components.

\section{Results}

Cotton leaf area index (LAI)

Cultivars had no significant effect on LAl; hence, the results in Fig 2 are averaged over cultivars FM 913GLT and FM 983GLT. In the first season, at 60 DAE LAI was higher when $\mathrm{K}$ was applied to cotton without ruzigrass, just to ruzigrass or split into ruzigrass and cotton as compared with the other tratments (Fig. 2a). In the second year, there was no difference between treatments at $30 \mathrm{DAE}$, but at 60 and $90 \mathrm{DAE}$ 
$\mathrm{K}$ fertilization in cotton without ruzigrass increased LAl, which was decreased in the presence of ruzigrass without $\mathrm{K}$ (Fig. 2b). At $120 \mathrm{DAE}$, a reduction in LAl was observed in the treatment where there was no $\mathrm{K}$ and ruzigrass, and it was increased when $\mathrm{K}$ was applied to ruzigrass.

Stomatal conductance (gs)

Stomatal conductance ( $\mathrm{gs}$ ) at F1 (Fig. 3a) showed no difference between treatments in the first year of the study (2016/2017). In the second year (2017/2018), gs was lower in the absence of K, irrespective of ruzigrass, or when $\mathrm{K}$ was applied to cotton without ruzigrass. A response to $\mathrm{K}$ application was observed only when there was enough rain, in the second year. At F7, gs increased in the second year (Fig. 3b). A reduction was observed in $\mathrm{g}_{s}$ at peak flowering ( $\mathrm{F} 7$ stage) in the absence of $\mathrm{K}$ and ruzigrass $(\mathrm{KK})$ in $2016 / 17$ and in the absence of $\mathrm{K}$ in $2017 / 18$, irrespective of the grass. A reduction on gs at C2 was observed in 2017/2018 in K unfertilized treatments.

\section{Enzymatic activity}

Soluble Acid Invertase - SAI

SAl activity in cotton leaves was higher when $\mathrm{K}$ fertilization was applied on ruzigrass + cotton (58K on RZ $+58 \mathrm{~K}$ on $\mathrm{C}$ ) and when it was performed fully on cotton without ruzigrass on early cultivar (FM 913GLT) but for the late cultivar (FM 983GLT), SAl activity was increased by $\mathrm{K}$ fertilization on cotton without ruzigrass (Fig. 4a). In both cultivars, the lowest SAl activity was observed in the absence of $\mathrm{K}$ and ruzigrass. Early cultivar FM 913GLT had higher SAl activity when $\mathrm{K}$ was split in ruzigrass and cotton, but the full K application on ruzigrass resulted in higher SAl activity in the late cultivar (FM 983GLT).

Sucrose Phosphate Synthase - SPS

The greatest SPS activity was found in the treatment where $\mathrm{K}$ fertilization was applied entirely on cotton and it was slightly higher in the presence of ruzigrass for the late cultivar and the lowest in the absence ok K and ruzigrass (Fig. 4b). SPS activity in the early cultivar was improved by $\mathrm{K}$ fertilization on cotton after ruzigrass. Furthermore, the early cultivar FM $913 \mathrm{GLT}$ showed greater SPS activity in most K managements, except where full $\mathrm{K}$ fertilization was applied to the late cultivar FM 983GLT with or without ruziziensis.

\section{Sucrose Synthase - SuSy}

The highest SuSy activity in both cultivars was found when $\mathrm{K}$ was applied to cotton in the absence of ruzigrass (Fig. 4c), while the lowest was observed in the absence of $\mathrm{K}$ fertilization and ruziziensis. Also, late cultivar FM 983GLT had higher SuSy activity in most treatments, but the early cultivar showed higher SuSy activity when receiving $\mathrm{K}$ in the absence of ruzigrass. In both cultivars, when $\mathrm{K}$ was applied on ruzigrass and cotton, Susy activity increased. 
Splitting $\mathrm{K}$ fertilitazion half on ruzigrass and half on cotton increased the cellulose content in the cotton fiber 24 days after anthesis (DAA). It is interesting that even applying $116 \mathrm{~kg} \mathrm{ha}^{-1}$ of $\mathrm{K}$ to cotton in the absence of ruzigrass, the fiber cellulose content was similar to those in the absecence of K (Fig. 5a). At $48 \mathrm{DAE}$, when the cellulose contents were higher for both cultivars, there was no difference in cellulose content between treatments (Fig. 5b). However, the early cultivar (FM 913GLT) accumulated more cellulose in the fiber at 24 DAA than FM 983 GLT.

\section{Principal Component Analysis}

The principal component analysis for each cultivar showed a separation of treatments considering the analyzed variables. The PCA performed with all the data for cultivar FM 913 GLT (Fig. 6) represented 46\% of the total variation of the original data by principal component 1, but PC2 was not significant. The parameters for discrimination in the main component 1(PC1) were LAl 120 (eigenvector $=-0.9217$ ), LAI 90 (eigenvector $=-0.8885)$, and SPS (eigenvector $=-0.8047)($ Table 2). Plants without $\mathrm{K}$ and different treatments were separated at the left and right ends, respectively.

For the cultivar FM 983GLT (Figure 7) PC1 comprised 36\% and PC2 was not significant. The most important parameters for discrimination in PC1 were SAI (eigenvector $=-0.8911$ ), SUSY (eigenvector $=$ -0.8713 ), and LAI 120 (eigenvector $=-0.7661$ ). The ordination graph showed that groups were separated according to $\mathrm{K}$ fertilization. The greater distance between with and without $\mathrm{K}$ application indicated the sensitivity of K-treated plants compared with not K-treated plants in both cultivars.

\section{Discussion}

Potassium management did not affect LAl early in the growing cycle in both seasons (Fig 2), probably because cotton canopy growth is slow at this stage, as the plant invests most of the carbohydrates to develop its root system (Echer et al. 2019). However, at 60 and 90 DAE in the first season and 60, 90 and 120 DAE in the second season, LAl was higher when the plant was fertilized with $\mathrm{K}$, as a result of the increased leaf area and life span, as the leaf's life is reduced by K deficiency (Wright 1999).

Potassium plays a key role in stomatal regulation (Langer et al. 2004). However, in this experiment $\mathrm{K}$ management did not affect gs at the F1 stage in 2016/17 (Fig 3), which may be associated with good water availability, since it rained the day before the assessment (Fig 1). This finding confirms the role of grasses such as ruzigrass in K cycling (Echer et al. 2020) and the improvement on plant physiological apparatus. When the $\mathrm{K}$ rate was split, cotton showed higher stomatal conductance at $\mathrm{F} 7$ (full flowering stage) in both seasons. The effect of $\mathrm{K}$ on $\mathrm{g}_{s}$ is well reported in the literature (Zhao et al. 2001; Hu et al. 2016; Hu et al. 2017), but this finding shows the benefit of splitting $K$ fertilization in sandy soils on cotton physiology. At the latest stage C2 ( $1^{\text {st }}$ open boll in the $2^{\text {nd }}$ fruiting branch) the severe reduction in soil humidity limited treatment responses. Additionally, in the second season, $\mathrm{K}$ fertilization associated to ruzigrass resulted in higher $\mathrm{g}_{s}$, showing the importance of $\mathrm{K}$ management on leaf life span (LAl) and activity $\left(\mathrm{g}_{s}\right)$. This may be the result of the $\mathrm{K}$ released from the decaying grass during cotton growth 
improving $\mathrm{K}$ use efficiency in the system. During boll filling there is a high demand for carbohydrates from photosynthesis and proper $\mathrm{K}$ nutrition can support gas exchange as $\mathrm{K}$ is remobilized to fruits in high rates (Rosolem and Mikkelsen 1991).

SAl catalyzes the hydrolysis of sucrose into glucose and fructose (Winter and Huber 2000); SPS is directly related to sucrose synthesis from carbon fixed by photosynthesis (Mendicino 1960), and SuSy's main function is to cleave sucrose for starch synthesis and cell wall construction (Déjardin et al. 1997; Nakai et al. 1999). Our results show that potassium fertilization was essential to keep the activities of enzymes involved in carbohydrate metabolism (SAI, SPS and SuSy) at an adequate level (Fig 4). In addition, the increase in the activity of these enzymes is potentially linked to $\mathrm{K}$ leaf concentration (Hu et al. 2017; Zahoor et al. 2017; Tung et al. 2018, Ali et al. 2018). Studies reported changes in the leaf sucrose or starch contents and increased enzyme activity and carbohydrate metabolism by K application in cotton (Wang et al. 2012; Hu et al. 2015; Zahoor et al. 2017; Ali et al. 2018).

There is a strong relationship between cell elongation and leaf $\mathrm{K}$ concentration, since the hormones that stimulate cell elongation are highly dependent on adequate levels of $\mathrm{K}$ in plant tissues (Cakmak 2005). The qualitative characteristics of cotton fibers are positively influenced by an adequate supply of $K$, as this nutrient regulates the crop cycle, maintains the leaf area, and provides greater cellulose deposition on the inner walls of the fibers improving micronaire index (Carvalho et al. 2006; Hafeez et al. 2019). Indeed, during the fiber-thickening process, SAI, SPS and SuSy serve as the main enzymes for cellulose synthesis, and their activities are highly dependent upon K application rate (Zahoor et al. 2017; Tung et al. 2018; Ali et al. 2018), corroborating our results and showing that $K$ application in cotton resulted in increased enzymatic activity concomitantly with the increase in cellulose deposition in the fibers (Fig 4 and 5).

The results of the PCAs confirmed that both cultivars were sensitive to K supply. Early cultivar FM 913GLT also showed that there was a significant correlation between carbohydrate enzymes (SAI, SPS, and SUSY) and the LAI at 90 and $120 \mathrm{DAE}$, and the reduction in $\mathrm{g}_{s}$ and LAl at $30 \mathrm{DAE}$. Also, the responses of the late cultivar (FM 983GLT) were explained by the reduction in $\mathrm{g}_{s}$ and LAl at 30 and 60 DAE. SAI, SPS and SuSy activities increased in cotton leaves under $\mathrm{K}$ fertilization, which explains the higher sucrose synthesis than in the absence of K (OK). However, cellulose content was affected only at 24 DAA, indicating that the application of half of the $K$ to the grass and half to cotton can improve cellulose deposition early in the fiber development.

\section{Conclusion}

Potassium fertilization improves physiological parameters such as LAl in a year with a regular rainfall distribution, and when associated with the use of grass, improves stomatal conductance late in the season. The absence of K impairs activity of the enzymes SAI, SPS and SuSy, but the effect is cultivar dependent. Early cellulose accumulation in the fiber is favored when cotton is grown after ruzigrass.

\section{Declarations}


Acknowledgements

The authors thank the Foundation for Research Support of the State of São Paulo (FAPESP) for their support through a Master's scholarship granted to Peres, V.J.S. (grant 2016/16736-4). This work was partially funded by Fundação Agrisus (grant PA 1918/16) and by APPA (São Paulo Cotton Grower's Association).

Funding - Foundation for Research Support of the State of São Paulo (FAPESP) (grant 2016/16736-4). Fundação Agrisus (grant PA 1918/16) and by APPA (São Paulo Cotton Grower's Association).

Conflicts of interest/Competing interests: The authors declare that they have no competing interests.

Availability of data and material: Not applicable

Code availability: SISVAR - Statistic Program (828459851).

\section{References}

Amorim, J. S. L. (2019). Correlação de Potássio Mehlich-1 com Potássio da solução de solos sob diferentes níveis de adubação.

Ali, S., Hafeez, A., Ma, X., Tung, S. A., Liu, A., Shah, A. N., et al. (2018) Potassium relative ratio to nitrogen considerably favors carbon metabolism in late-planted cotton at high planting density. Field Crops Research, 223, 48-56.

Bradford, M. M. (1976) A rapid and sensitive method for the quantitation of microgram quantities of protein utilizing the principle of protein-dye binding. Analytical Biochemistry, 72:248-254.

Bernardi, A. D. C., de Oliveira Júnior, J. P., Leandro, W. M., de MESQUITA, T. A., de Freitas, P. L., \& Carvalho, M. D. (2009). Doses e formas de aplicação da adubação potássica na rotação soja, milheto e algodão em sistema plantio direto. Embrapa Pecuária Sudeste-Artigo em periódico indexado (ALICE).

Cakmak, I. 2005. The role of potassium in alleviating detrimental effects of abiotic stresses in plants. Journal of Plant Nutrition and Soil Science, v. 168, p. 521-530.

Carvalho, M. C. S.; \& Ferreira, A. C. B. (2011). Manejo de solos aptos à cotonicultura no cerrado. In: Freire, E. C. (Ed.). Algodão no cerrado do Brasil. 2. ed. Aparecida de Goiânia: Associação Brasileira dos Produtores de Algodão, Cap. 19.

Cassman, K. G., Kerby, T. A., Roberts, B. A., Bryant, D. C., \& Higashi, S. L. (1990) Potassium nutrition effects on lint yield and fiber quality of Acala cotton. Crop Science, 30(3), 672-677.

Clement-Bailey, J., \& Gwathmey, C. O. (2007) Potassium effects on partitioning, yield, and earliness of contrasting cotton cultivars. Agronomy Journal. v. 99, p. 1130-1136. 
Copeland, L. (1990) Enzymes of sucrose metabolism. Methods in Plant Biochemistry, 3:73-85.

Dana, S.; Herdean, A.; Lundin, B.; \& Spetea, C. (2016) Each of the chloroplast potassium efflux antiporters affects photosynthesis and growth of fully developed Arabidopsis rosettes under short day photoperiod. Physiologia Plantarium, 158, 483-491.

Déjardin A., Rochat C., Wuillém S., \& Boutin J.P. (1997) Contribution of sucrose synthase. Plant, Cell and Environment, 1421-1430.

Duiker, S. W., \& Beegle, D. B. (2006) Soil fertility distributions in long-term no-till, chisel/disk and moldboard plow/disk systems. Soil Tillage Research, 88(1-2): 30-41.

Echer, F. R., Peres, V. J. S., \& Rosolem, C. A. (2020). Potassium application to the cover crop prior to cotton planting as a fertilization strategy in sandy soils. Scientific Reports, 10(1), 1-10.

Echer, F.R., Zanfolin, P.R.L., Moreira, A.C.M., Santos, A.C.P., \& Gorni, P.H. (2019) Root growth and carbohydrate partitioning in cotton subjected to shading in the initial phase. Ciência Rural 49.

Furlani Jr., E.; Silva, N. M.; Buzetti, S.; Sá, M. E.; Rosolem, C. A.; \& Carvalho, M. A. C. (2001) Extração de macronutrientes e acúmulo de massa seca de algodão cv. IAC 22. Cultura Agronômica, 10:71-87.

Foloni, J.S.S.; \& Rosolem, C.A. (2008) Produtividade e acúmulo de potássio na soja em função da antecipação da adubação potássica no sistema plantio direto. Revista Brasileira de Ciência do Solo 32(4): 1549-1561.

Gerardeaux, E.; Jordan-Meille, L.; Constantin, J.; Pellerin, S.; \& Dingkuhn, M. (2010) Changes in plant morphology and dry matter partitioning caused by potassium deficiency in Gossypium hirsutum L. Environmental and Experimental Botany, 67, 451-459.

Gormus, O., El-Sabagh, A., \& Islam, M. S. (2016) Optimizing yield and fiber quality of cotton under Mediterranean environment: managing nitrogen and potassium nutrition. Journal of Experimental Biology and Agricultural Sciences, 4(5 Suppl.), 572-580.

Grof, C. P., Albertson, P. L., Bursle, J., Perroux, J. M., Bonnett, G. D., \& Manners, J. M. (2007) Sucrosephosphate synthase, a biochemical marker of high sucrose accumulation in sugarcane. Crop Science, 47(4), 1530-1539.

Hafeez, A., Ali, S., Ma, X., Tung, S. A., Shah, A. N., Liu, A., et al. (2019) Sucrose metabolism in cotton subtending leaves influenced by potassium-to-nitrogen ratios. Nutrient Cycling in Agroecosystems, 113(2), 201-216.

Hu, W., Yang, J., Meng, Y., Wang, Y., Chen, B., Zhao, W., et al. (2015) Potassium application affects carbohydrate metabolism in the leaf subtending the cotton (Gossypium hirsutum L.) boll and its relationship with boll biomass. Field Crops Research, 179, 120-131. 
Hu, W., Coomer, T.D., Loka, D.A., Oosterhuis, D.M., \& Zhou, Z. (2017) Potassium deficiency affects the carbon-nitrogen balance in cotton leaves. Plant Physiology and Biochemistry, 115, 408-417.

Hu, W., Loka, D.A., Fitzsimons, T.R., Zhou, Z., \& Oosterhuis, D.M. (2018) Potassium deficiency limits reproductive success by altering carbohydrate and protein balances in cotton (Gossypium hirsutum L.). Environmental and Experimental Botany, 145:87-94

Huber, S. C.; \& Huber, J. L. (1991) Regulation of maize leaf sucrosephosphate synthase by protein phosphorylation. Plant and Cell Physiology, 32:319-326.

Kahrizi, D., Cheghamirza, K., Kakeai, M., Mohammadi, R., Ebadi, A. (2010) Heritability and genetic gain of some morphophysiological variables of durum wheat (Triticum turgidum var. durum). African Journal of Biotechnology 9:4469-4687.

King, S. P., Lunn, J. E., \& Furbank, R. T. (1997) Carbohydrate content and enzyme metabolism in developing canola siliques. Plant Physiology, 114:153-160.

Langer, K.; Levchenko, V.; Fromm, J.; Geiger, D.; Steinmeyer, R.; Lautner, S., et al. (2004) The poplar K+ channel KPT1 is associated with $\mathrm{K}^{+}$uptake during stomatal opening and bud development. The Plant Journal, 37:828-838.

Lima, J. J., \& Bélot, J. S. (2020) A fibra de algodão: qualidade e classificação. IMAmt.

McGarigal, K., Cushman, S., \& Stafford, S. (2000). Multivariate Statistics for Wildlife Ecology Research. Springer, New York, NY, USA.

Marur, C.J., \& Ruano, O. (2001) A reference system for determination of developmental stages of upland cotton. Revista de Oleaginosas e Fibrosas, 5:313-317.

Mendicino J (1960) Sucrose phosphate synthesis in wheat germ and green leaves. Journal of Biology and Chemistry 235: 3347-3352.

Nakai, T., Tonouchi N., Konishi T., Tsuchida T., Yoshinaga F., Sakai F., et al. (1999) Enhancement of cellulose production by expression of sucrose snthase in Acetobacter xylinum. Proceedings of the National Academy of Sciences. 14-18.

Oosterhuis, D. M., Loka, D. A., \& Raper, T. B. (2013) Potassium and stress alleviation: physiological functions and management of cotton. Journal of Plant Nutrition and Soil Science 176, 331343. https://doi.org/10.1002/jpln.20120 0414.

Parveen, Anwar-Ul-Haq, M., Aziz, T., Aziz, O., \& Maqsood, L. (2020) Potassium induces carbohydrates accumulation by enhancing morpho-physiological and biochemical attributes in soybean under salinity. Archives of Agronomy and Soil Science, 1-14. 
Pereira, J.R.A.; \& Rossi Jr, P. (1995) Manual Prático de Avaliação Nutricional de Alimentos. Piracicaba: FEALQ, 34p.

Pettigrew, W. T.; Heithold, J. J.; \& Meredith Jr., W.R. (1996) Genotypic interactions with potassium and nitrogen in cotton of varied maturity. Agronomy Journal, 88:89- 93.

Raphael, J. P. A.; Rosolem C. A.; \& Echer, F. R. (2020) Distribuição da produção no algodoeiro: conceitos, fatores ecofisiológicos, e implicações sobre a produtividade e sobre a qualidade da fibra. IMAmt.

Raij, B. Van; Andrade, J. C.; Cantarella, H.; \& Quaggio, J. A. (2001) Análise química para avaliação da fertilidade de solos tropicais. Campinas, Instituto Agronômico de Campinas, p. 285.

Rosolem, C. A., \& Bogiani, J. C. (2014) Nutrição e estresses nutricionais em algodoeiro. IMAmt.

Rosolem, C. A., \& Mikkelsen, D. S. (1991) Potassium absorption ans partitioning in cotton as affected by periods of potassium deficiency. Journal of Plant Nutrition, 14:1001-1016.

Rosolem, C. A; Echer, F. R., Lisboa, I. P., \& Barbosa, T. S. (2012) Acúmulo de Nitrogênio, fósforo e potássio pelo Algodoeiro Sob Irrigação Cultivado em Sistemas Convencional e Adensado. Revista Brasileira de Ciência do Solo, 36:427-466.

Rosolem, C. A., Almeida, D. S., Rocha, K. F. \& Bacco, G. H. M. (2017) Potassium fertilization with humic acid coated KCl in a sandy clay loam tropical soil. Soil Research, 56:244-251.

Rosolem, C. A., Santos, F. P. D., Foloni, J. S. S., \& Calonego, J. C. (2006) Potássio no solo em conseqüência da adubação sobre a palha de milheto e chuva simulada. Pesquisa Agropecuária Brasileira, 41, 1033-1040.

Saparov, A., Eleshev, R., Suleimenov, B., Peskovki, G., \& Shcherbakov, A. (2013) Effect of Potassium Chloride Application for Rice, Cotton and Potato in the Irrigated Zone of Kazakhstan. Better Crops with Plant Food. 97, 23-25.

Shabala, L.; Zhang, J.; Pottosin, I.; Bose, J.; Zhu, M.; Fuglsan, A.T.; et al. (2016) Cell-type specific $\mathrm{H}^{+}$ATPase activity in root tissues enables $\mathrm{K}^{+}$retention and mediates acclimation of barley (Hordeum vulgare L.) to salinity stress. Plant Physiology, 172, 2445-2458.

Shabala, S. (2017) Signalling by potassium: another second messenger to add to the list? Journal of Experimental Botany, 68:4003-4007.

Silva, N. M.; Carvalho, L. H.; Cia, E.; Fuzzatto, M. G.; Chiavegato, E. J.; \& Alleoni, L. R. F. (1995) Seja doutor do seu algodoeiro. Informações Agronômicas, Piracicaba, n. 69, mar. (Encarte, Arquivo do Agrônomo n. 8). 
Tung, S.A., Huang, Y., Ali, S., Hafeez, A., Shah, A.N., Song, X., et al. (2018) Mepiquat chloride application does not favor leaf photosynthesis and carbohydrate metabolism as well as lint yield in late-planted cotton at high plant density. Field Crops Research, 221:108-118

Van Soest, P.J.; Robertson, J.B.; \& Lewis, B.A. (1991) Methods for Dietary Fiber, Neutral Detergent Fiber, and Nonstarch Polysaccharides in Relation to Animal Nutrition. Journal of Dairy Science. 74, 3583-3597

Wang, N., Hua, H., Egrinya, A., Eneji, A., Li, Z., Duan, L., et al. (2012) Genotypic variations in photosynthetic and physiological adjustment to potassium deficiency in cotton (Gossypium hirsutum). Journal of Photochemistry and Photobiology B: Biology. 110, 1-8.

Wang R, Gao M, Ji S, Wang S, Meng Y, \& Zhou Z (2016) Carbon allocation, osmotic adjustment, antioxidant capacity and growth in cotton under long-term soil drought during flowering and boll-forming period. Plant Physioly and Biochemistry 107:137-146

Wang, Y.; \& Wu,W.H. (2017) Regulation of potassium transport and signaling in plants. Current Opinion in Plant Biology, 39, 123-128.

Winter H., \& Huber S.C. (2000) Regulation of sucrose metabolism in higher plants: localization and regulation of activity of key enzymes. Critical Reviews in Plant Science,31- 67.

Yang, G., Tang, H., Tong, J., Nie, Y., \& Zhang, X. (2012) Effect of fertilization frequency on cotton yield and biomass accumulation. Field Crops Research, 125, 161-166.

Werle, R., Garcia, R.A., \& Rosolem, C.A. (2008) Lixiviação de potássio em função da textura e da disponibilidade do nutriente no solo (Potassium leaching as affected by soil texture and potassium availability). Revista Brasileira de Ciência do Solo, 32: 2297-2305.

Zhao, D., Oosterhuis, D., \& Bednarz, C. (2001) Influence of potassium deficiency on photosynthesis, chlorophyll content, and chloroplast ultrastructure of cotton plants. Photosynthetica 39, 103-109.

Zahoor, R., Dong, H., Abid, M., Zhao, W., Wang, Y., \& Zhou, Z. (2017). Potassium fertilizer improves drought stress alleviation potential in cotton by enhancing photosynthesis and carbohydrate metabolism. Environmental and Experimental Botany. 137, 73-83.

\section{Tables}

Table 1. Selected chemical properties and particle size distribution of the soil 


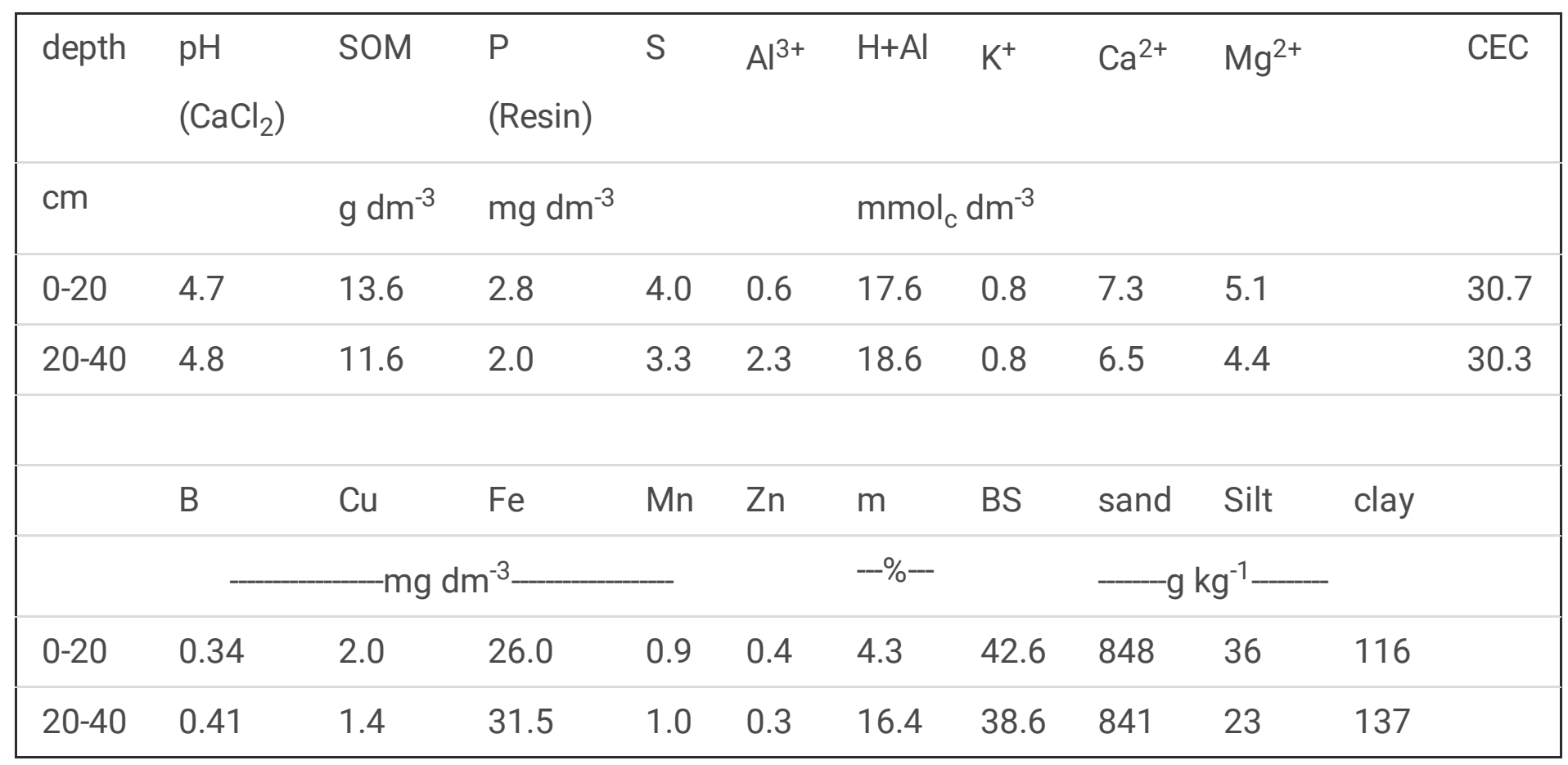

Table 2. Eigenvalues of all variables analyzed of FM 913GLT and FM 983GLT under different $K$ management and the use of ruzigrass

\begin{tabular}{|lll|}
\hline Total variance explained (\%) & FM 913GLT & FM 983GLT \\
\hline LAI 30 & -0.6417 & -0.0285 \\
\hline LAI 60 & -0.4406 & -0.3578 \\
\hline LAI 90 & -0.8885 & -0.7625 \\
\hline LAI 120 & -0.9217 & -0.7661 \\
\hline Gs F1 & -0.4848 & -0.0170 \\
\hline Gs F7 & -0.0224 & -0.5170 \\
\hline Gs C2 & -0.6766 & -0.2506 \\
\hline SAI & -0.7899 & -0.8911 \\
\hline SPS & -0.8047 & -0.6714 \\
\hline SUSY & -0.7150 & -0.8713 \\
\hline Cellulose & -0.6132 & -0.5821 \\
\hline
\end{tabular}

Table 2. Scheme of cotton $\mathrm{K}$ fertilization

DAE: days after emergence

Figures 


\begin{tabular}{|c|c|c|c|}
\hline Treatments & $\begin{array}{l}\text { Ruzigrass } \\
\text { (RZ) }\end{array}$ & $\mathrm{K}$ rate & Time of $\mathrm{K}$ fertilization \\
\hline $\mathrm{OK}$ & no & 0 & - \\
\hline $116 \mathrm{~K}$ & no & $\begin{array}{l}116 \mathrm{~kg} \\
\mathrm{ha}^{-1}\end{array}$ & $58 \mathrm{~kg} \mathrm{ha}^{-1}$ applied $30 \mathrm{DAE}$ and $58 \mathrm{~kg} \mathrm{ha}^{-1}$ at $45 \mathrm{DAE}$ \\
\hline $\mathrm{OK}+\mathrm{RZ}$ & yes & 0 & - \\
\hline $116 \mathrm{~K}$ on $\mathrm{RZ}$ & yes & $\begin{array}{l}116 \mathrm{~kg} \\
\mathrm{ha}^{-1}\end{array}$ & applied on RZ vegetative stage (90 DAE) \\
\hline $\begin{array}{l}58 \mathrm{~K} \text { on } \\
\mathrm{RZ}+58 \mathrm{~K} \text { on } \mathrm{C}\end{array}$ & yes & $\begin{array}{l}116 \mathrm{~kg} \\
\mathrm{ha}^{-1}\end{array}$ & $\begin{array}{l}58 \mathrm{~kg} \mathrm{ha}^{-1} \text { applied on } \mathrm{RZ} \text { vegetative stage and } 58 \mathrm{~kg} \mathrm{ha}^{-1} \\
\text { on cotton } 30 \mathrm{DAE}\end{array}$ \\
\hline $\begin{array}{l}116 \mathrm{~K} \text { on } \mathrm{C}+ \\
\mathrm{RZ}\end{array}$ & yes & $\begin{array}{l}116 \mathrm{~kg} \\
\mathrm{ha}^{-1}\end{array}$ & $58 \mathrm{~kg} \mathrm{ha}^{-1} 30 \mathrm{DAE}$ and $58 \mathrm{~kg} \mathrm{ha}^{-1} 45 \mathrm{DAE}$ \\
\hline
\end{tabular}



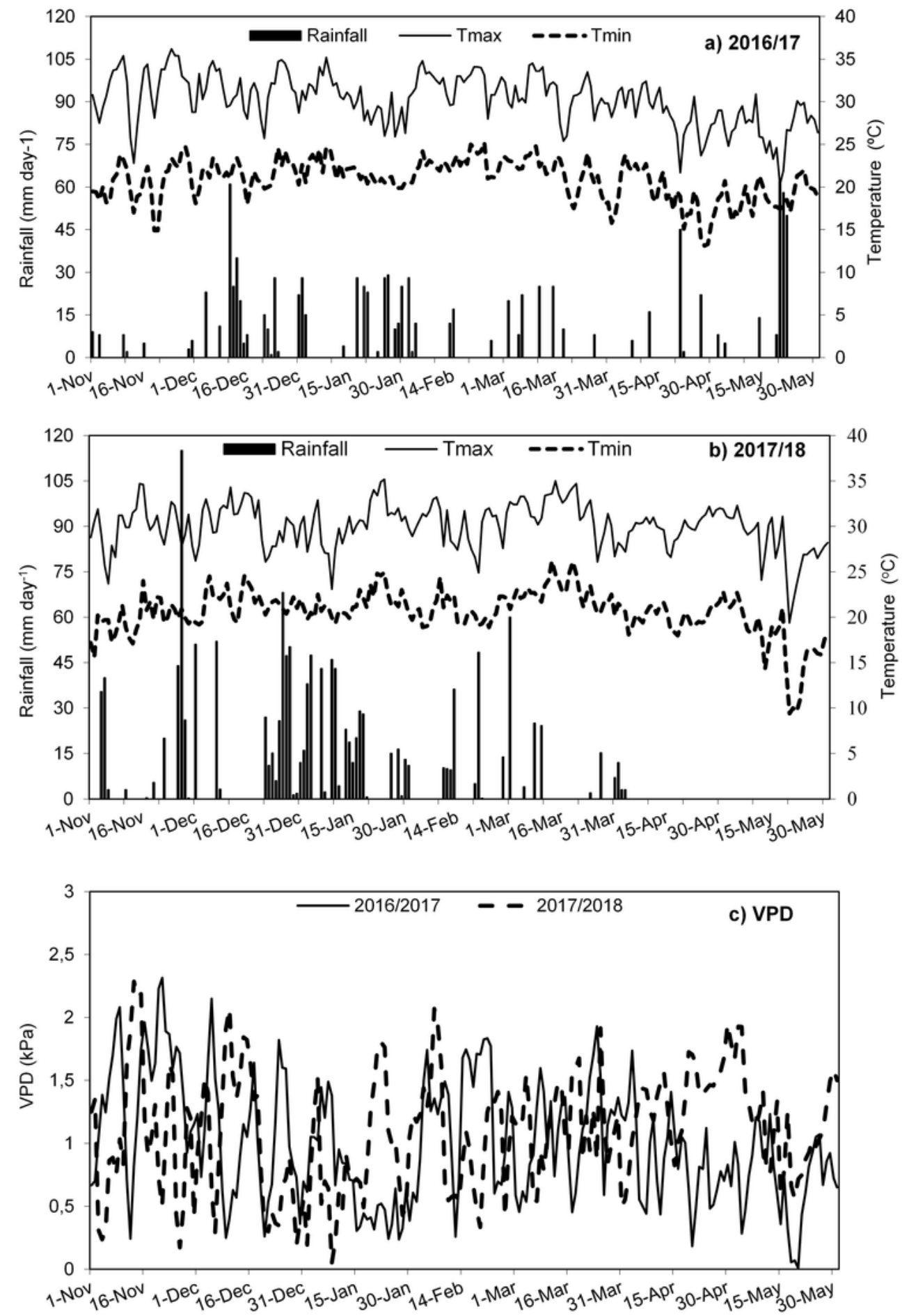

Figure 1

Rainfall, maximum and minimum temperatures, and vapor pressure deficit during the experiment. 


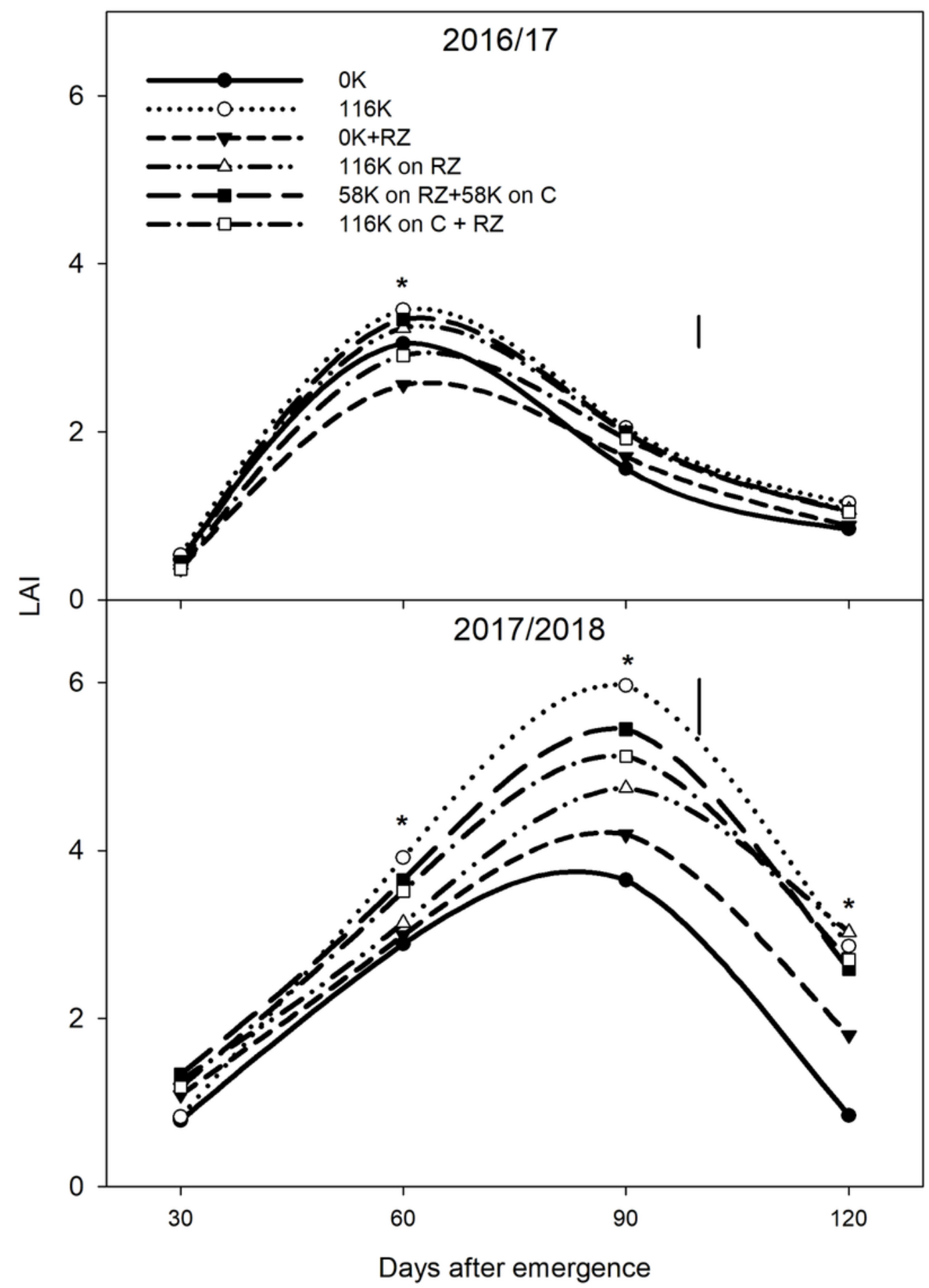

Figure 2

Cotton leaf area index (LAI) as affected by K management in the 2016/17 (a) and 2017/18 (b) seasons. Vertical bars show the least significant difference (Tukey test, $P<0.05$ ). 


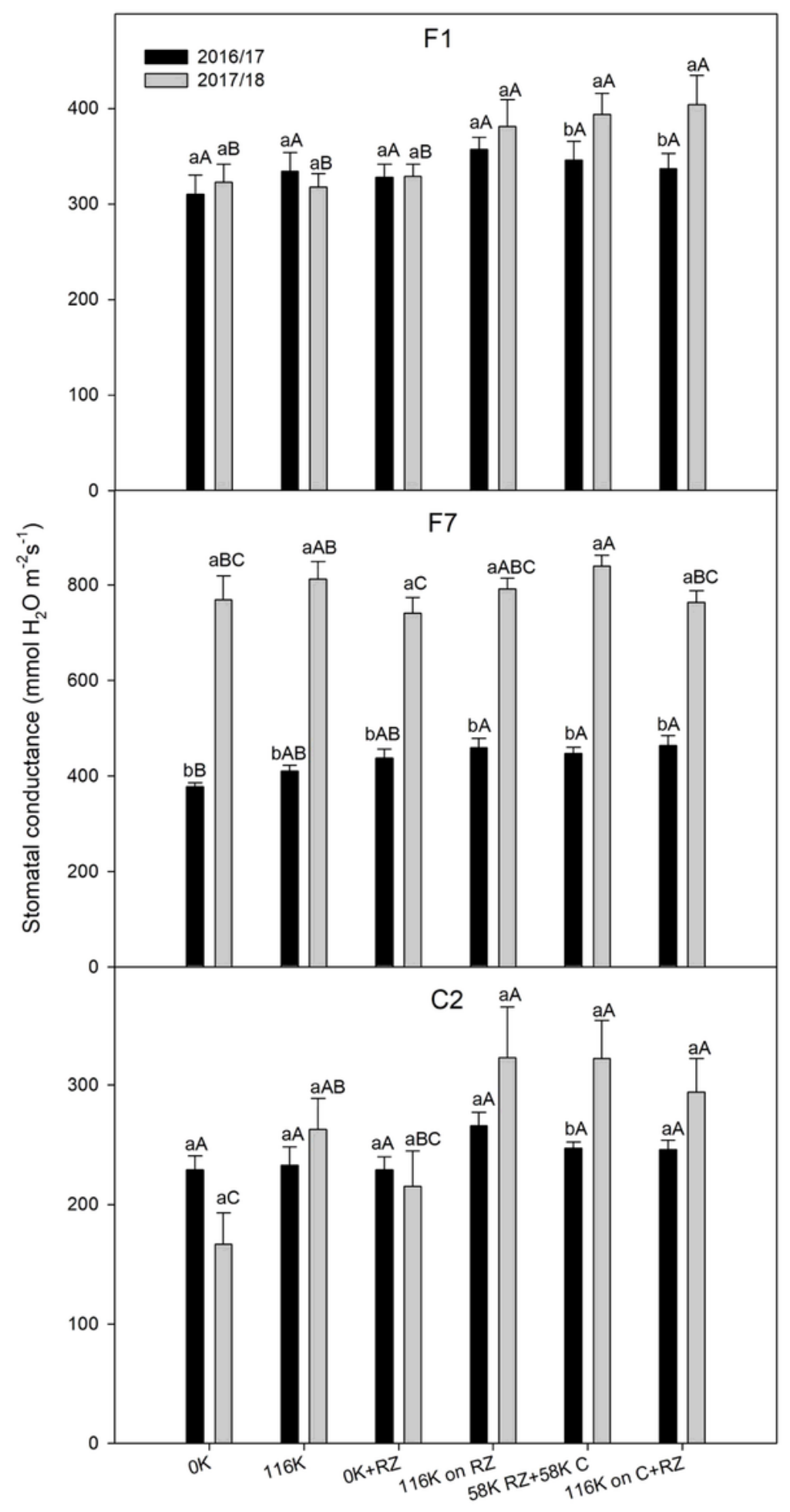

Figure 3

Stomatal conductance of cotton leaves (averaged across two cultivars) at phenological stages F1 (1st flower), F7 (peak flowering) and C2 (2nd cracked boll). Uppercase letters compare K managements and lowercase letters compare years in each $\mathrm{K}$ management. (Tukey test, $\mathrm{P}<0.05$ ). 


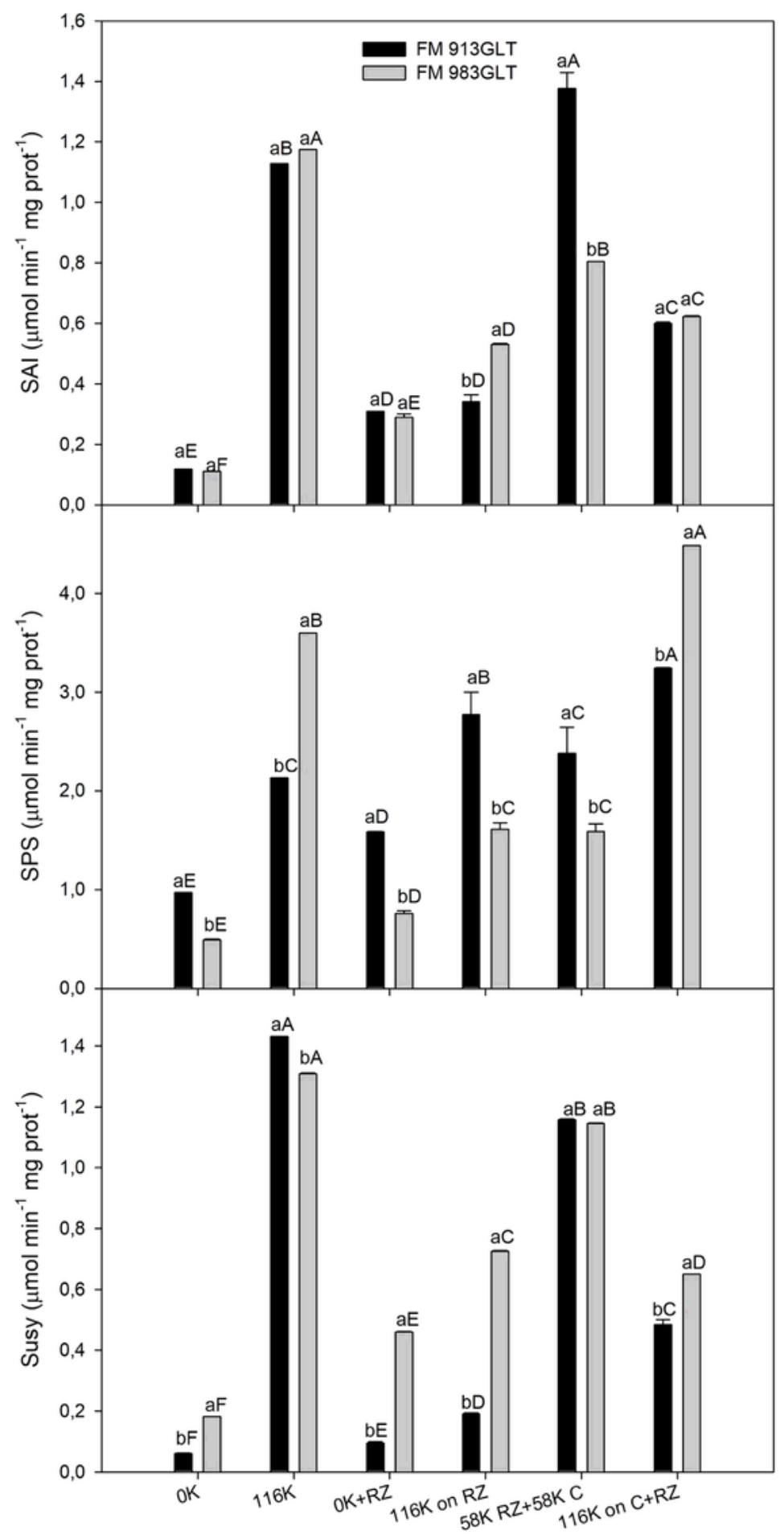

Figure 4

Activity of soluble acid invertase (SAI), sucrose phosphate synthase (SPS), and sucrose synthase (SuSy) as affected by $\mathrm{K}$ fertilization management and cotton cultivars. Uppercase letters compare $\mathrm{K}$ management, and lowercase letters compare cultivars in each $\mathrm{K}$ management. (Tukey test, $\mathrm{P}<0.05$ ). 


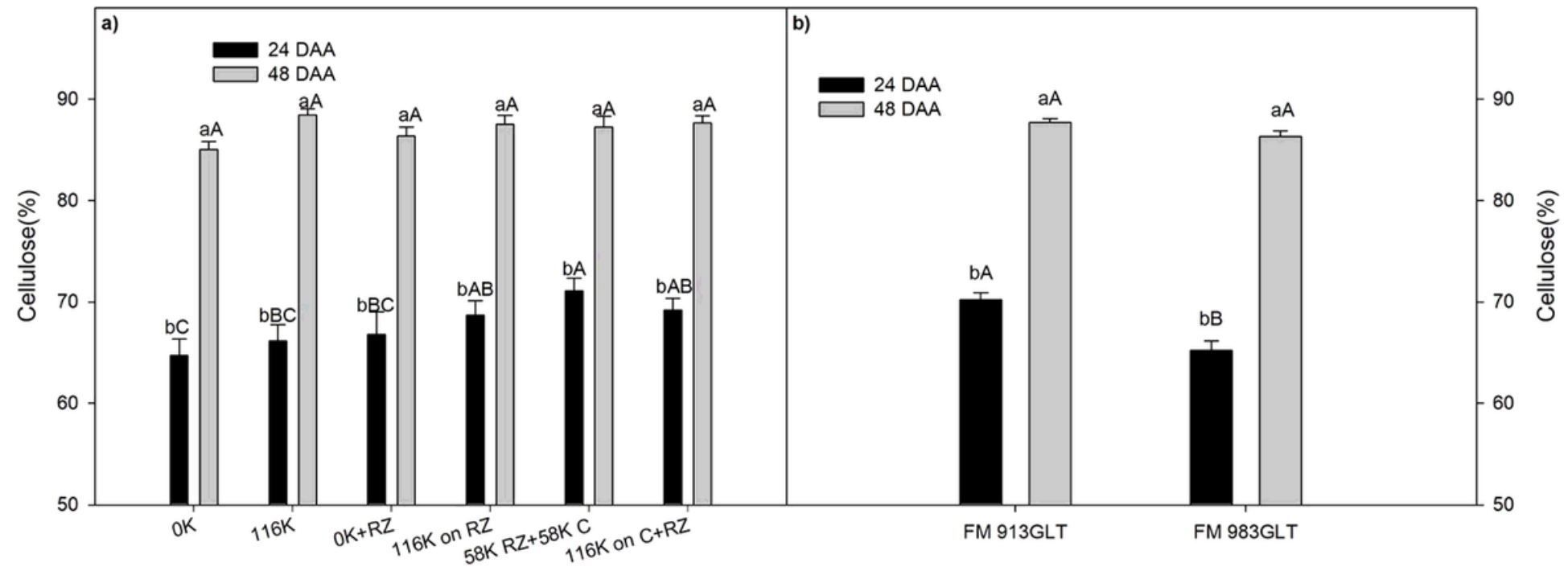

Figure 5

Cellulose content in cotton fibers in the middle third of the plants (10th node) at 24 and 48 days after anthesis (DAA) as affected by $\mathrm{K}$ fertilizer management (a) and cotton cultivar (b). Uppercase letters compare $\mathrm{K}$ management (DAA) and lowercase letters compare boll age in each $\mathrm{K}$ management $(\mathrm{a})$ or cultivar (b). (Tukey test, $\mathrm{P}<0.05$ ).

913

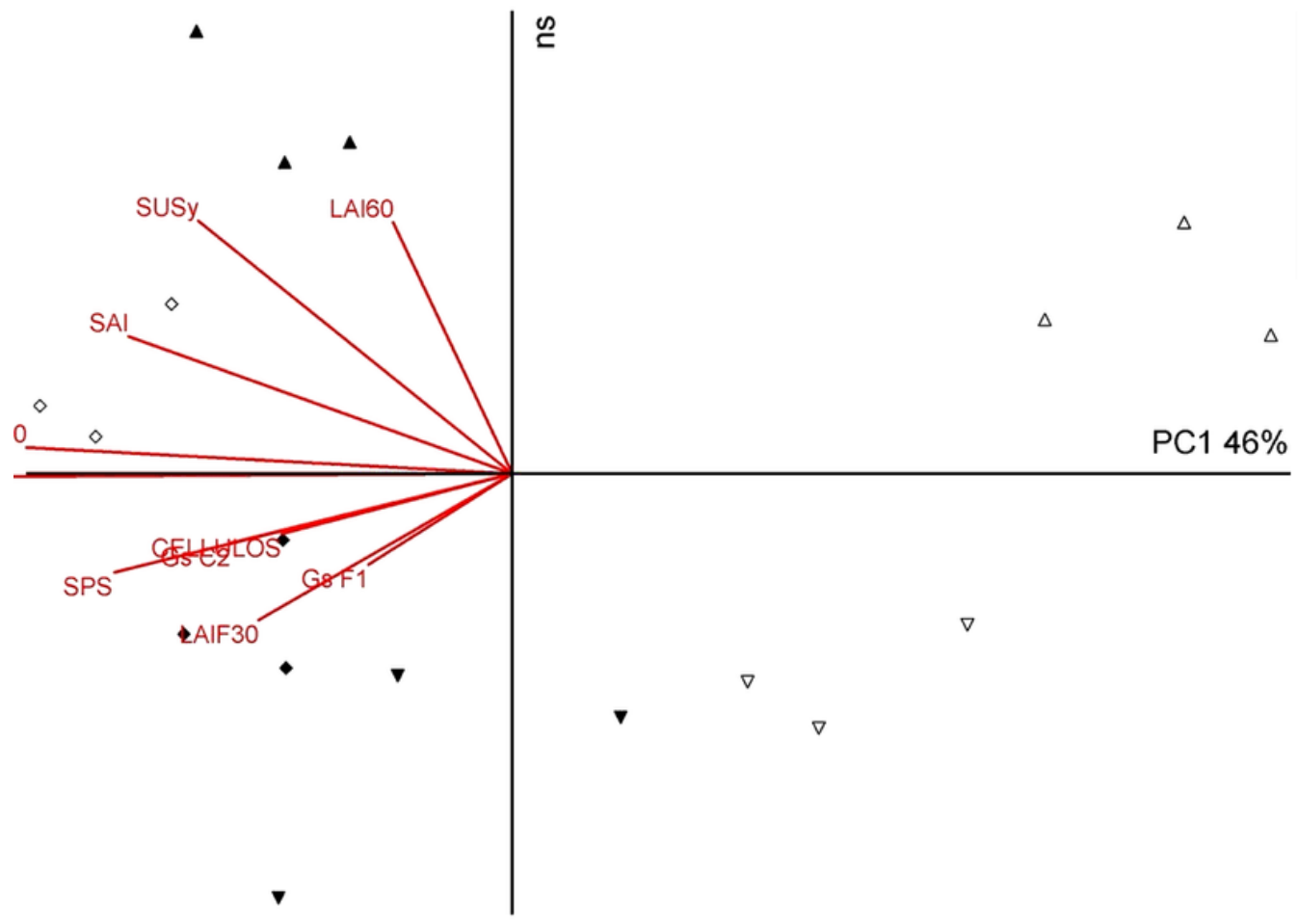

Figure 6 
Principal Component Analysis for early cultivar (FM 913GLT). Percentage of data variation in PC1 $=46 \%$; PC2 was not significant.

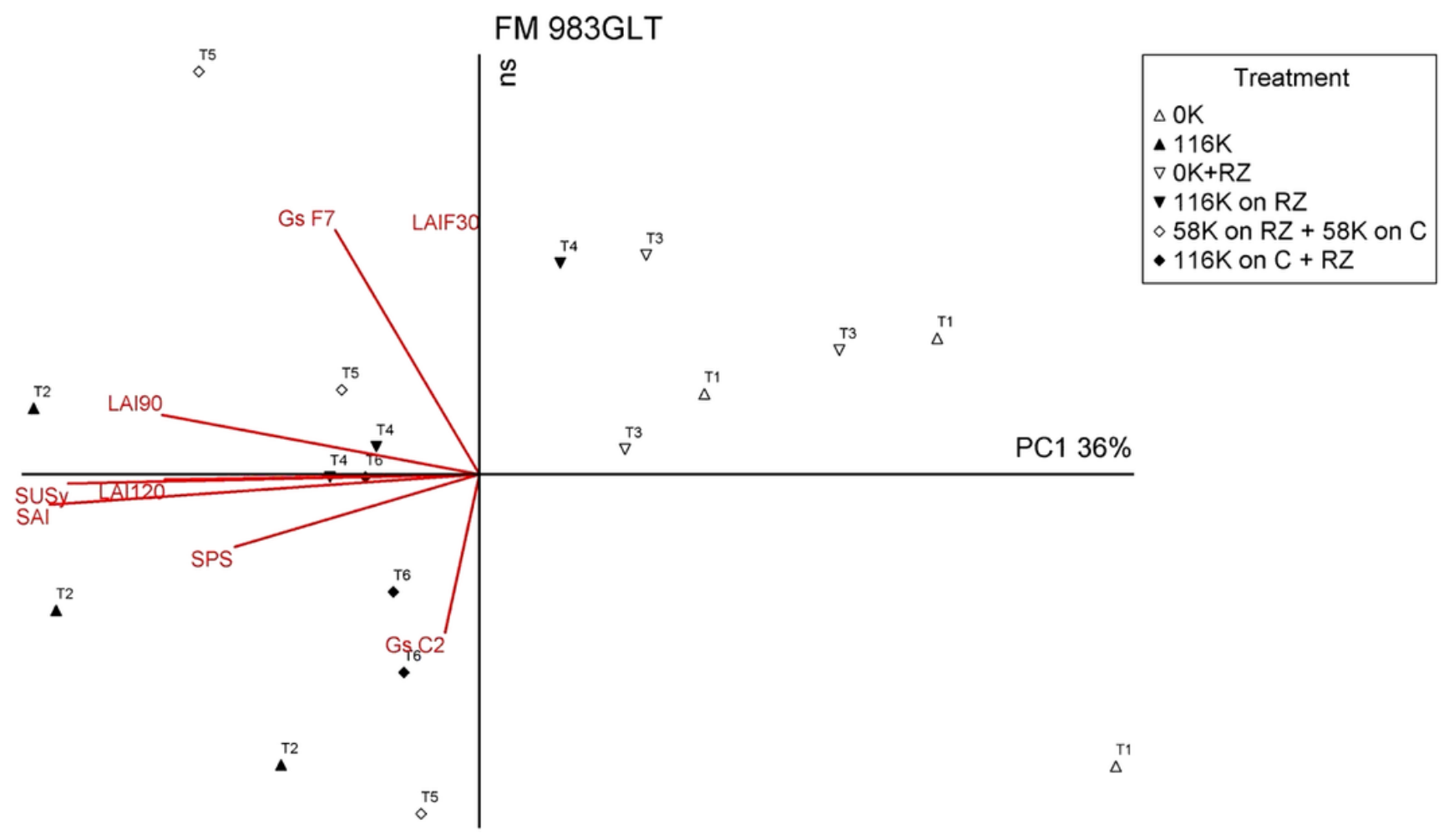

\section{Figure 7}

Principal Component Analysis for late cultivar (FM 913GLT). Percentage of data variation in PC1 $=36 \%$; PC2 was not significant. 